\title{
LEGAL INSTRUMENTS TO CONSIDER IN STRUCTURING PARENTING PLANS
}

\section{Tanya Robinson, Linda Stewart, Elma Ryke, Cornelia Wessels}

\section{INTRODUCTION}

The objective of this article is to provide the legal context of parenting plans in South Africa. The Children's Act 38 of 2005 (hereafter Children's Act) makes explicit provision for parenting plans. It is therefore important to analyse the relevant provisions in terms of the Constitution of the Republic of South Africa (1996) (hereafter Constitution) and the Children's Act, read together with international and regional children's rights instruments pertaining to parental rights and responsibilities to establish their nature and content of these plans as well as their necessity. Section 33(3) of the Children's Act states that a parenting plan may determine any matter in connection with parental responsibilities and rights, including (a) where and with whom the child is to live; (b) the maintenance of the child; (c) contact between the child and (i) any of the parties, and (ii) any other person; and (d) the schooling and religious upbringing of the child.

A legal context of parenting plans will give the reader an understanding of the rationale of the research to develop substantive guidelines for mental health professionals, for example, social workers, psychologists and legal professionals such as attorneys and advocates (hereafter professionals) pertaining to parenting plans. Substantive guidelines that are comprehensive and clear on the basic structure and general content of these plans are needed for professionals, as the researchers are of the opinion that professionals are often not well grounded in the legal requirements of facilitating, formulating and adopting or implementing a parenting plan. It can have devastating effects on the divorcing family, and specifically on the child, if the proposed parenting plan is not workable or realistic or if it is inadequate (in the sense that it lacks content and substance) for the family in question, and this may result dysfunctional situations such as stress for the child.

Bastow (2009:2), Pretorius (2008:15), Ramolotja (2000:2) and Robinson (2009:79) indicate that the professional as well as the parents can easily lose sight of the purpose of a parenting plan - that of having the child's best interest at heart and being child-centred and not parentcentred. The researchers frequently found in practice that parenting plans are built around the wishes and needs of the parents and not those of the children. This is merely one of many problems in the practice of parenting plans.

The researchers will analyse and critically discuss a number of legal instruments pertaining to children. As a point of departure, the Constitution (being the highest law in South Africa) will be discussed, and more specifically section 28. Section 28 is part of Chapter 2 of the Constitution and deals exclusively with the fundamental or human rights of children. These rights, as contained in the Constitution, have been translated into legal subjective rights in the Children's Act. It is therefore necessary to evaluate the relevant sections in the Children's Act which deal with parental plans and related issues. Section 39 of the Constitution requires a court interpreting a fundamental right in Chapter 2 of the Constitution to take international law into account as well. Another reason to consider relevant international and regional law is the fact that the South African government had signed and ratified the United Nations Convention of the Rights of the Child (UNCRC) and the African Charter on the Rights and Welfare of the Child (ACRWC), which places a duty on the government to adhere to these documents and 
translate the provisions of these documents into domestic legislation. Through a critical analysis of these legal instruments, the researchers anticipate obtaining insight into, and an understanding of, legal instruments and the way that they prioritise the child, and the way that a child-centred approach should influence the contents of parenting plans. This will also make clear what is required by these documents for the purposes of formulating a parental plan.

\section{PROBLEM STATEMENT}

Section 28 of the Constitution, which exclusively deals with children's rights and which is part of the Bill of Rights in the Constitution, is central to this study. Of particular importance are subsections 1(b) and (2). The first deals with family and parental care:

1. Every child has the right - (b) to family care, parental care, or appropriate alternative care when removed from the family environment;

and the second re-emphasises the child-centred approach by making the best interest of the child of paramount importance in any matter concerning the child:

2. a child's best interest is of paramount importance in every matter concerning the child.

These rights have been concretised in legislation, and especially the Children's Act.

However, in practice the child has not been prioritised when parents enter into divorce proceedings. There is a gap between the protection of the child, which the state attempts to facilitate, and what happens in practice when professionals work with divorcing families. Consequently, the researcher is of the opinion that by and large the best interest of the child rarely receives proper attention and priority when the parents of the child decide to divorce. Currie and De Waal (2005:617), in concurrence with Ramolotja (2000:1), Tayer and Zimmerman (2001:165) and White (2005:22), indicate that when a family goes through divorce proceedings, it is the child's rights that should be emphasised and not the rights of the parent. The provisions of the Constitution and especially the Children's Act should be enforced rigidly to ensure that children receive the proper protection and prioritisation when professionals are required to draft, formulate and facilitate parenting plans. A parenting plan should thus clearly reflect the child's needs, wishes and sense of safety, and it should ensure that the rights of the child are respected, protected, promoted and fulfilled in accordance with the Constitution and the Children's Act.

The researchers experienced these problems with the drafting of parenting plans for divorcing families. It was then necessary to verify whether these were indeed problems other professionals are also faced with and, if so, to establish means to address these problems areas. Parents often insist on being the main focus in the intervention process and do not want the professional to consult with the child. Furthermore, the parent liable for the professional bills expects to be the 'prioritised client', who is entitled to make a bigger input in the process and to have the final say. Clients consult with various professionals until they feel content with the recommendations that promote the clients themselves and their needs. Often attorneys represent their adult clients, while the child is not accommodated in the process. Professional conflict about recommendations leads to further disagreement, which affects the family even more. In this process the parents' conflict becomes the main focus of the process instead of the child's rights and interests. Professionals do not consult with the children and children are not heard in the process: the result of this is that parenting plans are designed which are focused on the parents' wants and needs rather than on the best interest of the children. 
These problems should be prevented by developing parenting plans that are child-centred. Carter, Haave and Vandersteen (2010:1) offer a number of guiding values for child-centred parenting plans, for example:

- Parenting plans should minimise loss and maximise relationships for children;

- Stability of placement should be considered in the context of the developmental needs of the child;

- Parents are more important than alternative care providers for the child;

- The parenting plan must consider the needs of the older child for peer contact and the changing parent/child relationship;

- School-age children may need multiple parenting plans: one for the regular school year, one for summer vacation, one for winter vacation and one for spring break;

- Regardless of the schedule, children should be with their mother on her birthday and on mother's day, and with their father on his birthday and on father's day;

- Children are unique individuals and should each benefit from some one-on-one time with their parents;

- The role of parents is to cooperate to provide as many opportunities for their children as possible; and

- Clear definitions of terms are required, for example: "a weekend begins when the child leaves the school for the last time before Saturday. The weekend ends when the child enters the school for the first time after Sunday."

The researcher agrees with all the above-mentioned guiding values for child-centred parenting plans and believes that these values should be incorporated into child-centred parenting plans. However, the above stated values are formulated for Hawaii, while South Africa is in need of similar tested values that have not yet been developed. These guiding values need to be context specific and thus the need for this article to analyse the legal context to enable prospective guiding values for parenting plans. The child's wishes (what the child wants) and best interest (what is good for the child) must form part of a child-centred parenting plan. However, it is important that when the child's wishes are not necessarily in his or her best interest as determined by a professional, the best interest of the child (as determined by a professional) should take priority over the wishes of the child. The contention is further held that when parenting plans are developed and implemented, the emphasis should be on the child and on the requirements of legal instruments pertaining to children.

This research is guided by the following research question: What legal issues and factors do professionals have to consider when a parenting plan is created? The researcher aims to answer the above question through critically analysing relevant provisions pertaining to parenting plans in these legal instruments. As a point of departure, section 28 of the Constitution is analysed, followed by the United Nations Convention of the Rights of the Child; the African Charter on the Rights and Welfare of the Child; and the Children's Act. Insights gained through these legal instruments are then used to set general guidelines taken from the legal findings.

\section{THE CONSTITUTION OF THE REPUBLIC OF SOUTH AFRICA, 1996}

Today South African society is guided by a Constitution that recognises the rights and the equality and dignity of everyone, including children. During the drafting of the Constitution, 
the United Nations Convention on the Rights of the Child (UNCRC) played a critical role to ensure that children's rights were entrenched in the Constitution. The Bill of Rights in South Africa's Constitution safeguards the human rights of all adults and children alike. The purpose of the Constitution is to create a society that is based on equality, dignity and freedom. Children have the same rights as adults, with a few age-related exceptions, such as the right to vote and the right to stand for public office. In addition, the Bill of Rights further specifies a number of rights contained in section 28 which apply only to children (Situational Analysis of Children in South Africa, 2009:3,4).

Section 28 of the Constitution is particularly relevant to this study. It was explained in the problem statement above that section 28 should be considered as a point of departure and a baseline to fully comprehend the subjective rights of the child contained in legislation such as the Children's Act when a parenting plan is being drafted.

The Constitution emphasises certain important aspects that the researcher believes should be taken into consideration with parenting plans. The researcher is of the opinion that when professionals facilitate the process of intervention with a divorcing family, they should consider the following, as reflected in the Constitution, to enable the professional to draft a parenting plan. Firstly, a parenting plan should clearly reflect the child's right to parental care. Secondly, the child should be protected by the professional recommendations made in the parenting plan. A developmental approach is an approach that takes into consideration the child's needs from birth to age 18 and it focuses on age-appropriate recommendations. Such a developmental approach to child care and protection is to achieve a situation where most children are participating in, and are cared for by, well-functioning families, who are able to claim their rights. Close-knit families, inspirational parents, loving grandparents and welcoming extended families are critical conditions for children's happy family experiences (Situational Analysis of Children in South Africa, 2009:xx). The researcher has observed that in a divorcing family, the family often experiences a period of dysfunction - therefore it is imperative that the professional structure of a parenting plan ensures that the child remains cared for and protected within the period of dysfunction as well as the period when the family recovers and becomes functional after the divorce.

Thirdly, it is imperative that the child as well as the parents be informed that the child has the right to legal representation, as the child's wishes (what the child wants) and best interest (what is good for the child) should be considered in the formulation of a parenting plan. The wishes and the best interest of the child should, however, be professionally evaluated as children's perception of what may be good for them may be different from the professional's view based on experience and knowledge. The best interest of the child thus takes priority over the wishes of the child as evaluated by a professional. The researchers often see parents who are represented by legal counsel, but have seldom seen that children have their own appointed legal representation. A shift in this practice is necessary, so that children are represented fully by legal counsel, especially in the intervention process, to facilitate parenting plans that give a voice to the child.

Lastly, the child's best interest should be prioritised throughout the process of facilitating intervention and making recommendations in a parenting plan. Boston (2009:2), Pretorius (2008:15), Ramolotja (2000:2) and Robinson (2009:79) indicate that while working with divorcing families, the professional is often placed under pressure by co-professionals (legal counsel that represents a parent) or the parents themselves to make decisions and/or recommendations in favour of the parents, or decisions which will suit the parents. It is 
imperative that the professional not give in to intimidation in the process, but that he/she should remain focused on the needs and wishes of the child and act on behalf of the child, as it is important that the child is seen as the client and not the parents.

The researchers identified four points in section 28 - namely (1) the child's right to parental care, (2) the child should be protected, (3) the child has the right to legal representation, and (4) the child's best interest - that will enable professionals to place the primary focus on the child and that will assist them in their work with divorcing families and their drafting of parenting plans.

The United Nations Convention on the Rights of the Child will be discussed in the section below.

\section{THE UNITED NATIONS CONVENTION ON THE RIGHTS OF THE CHILD}

South Africa signed and ratified the United Nations Convention on the Rights of the Child (UNCRC). In terms of the UNCRC, South Africa - as a state party - is required to measure progress towards fulfilling children's rights and to report to the UN Committee every five years. The specific provisions for children's rights in the South African Constitution were aligned with the UNCRC, which must be taken into account in the interpretation of the constitutional rights of children in South Africa. According to the UNCRC, every child has the right to survival, development, protection and participation. All four these generic rights are pertinent to each of the categories of rights, wellbeing and vulnerability, as reflected in the UNCRC (Situational Analysis of Children in South Africa, 2009:6).

Archard and Skivenes (2009:1), Gould and Martindale (2009:33) and Stahl (1999:25) explain that two central commitments are made in the law and policy that operate in Western jurisdictions with respect to children: to promote the child's best interests or the child's welfare; and to allow the child to express his or her view of any matter affecting his or her interests, these views being given a weight proportionate to the child's maturity, age and understanding of these issues. These two commitments have practical application in all the key areas where a child's interests are at stake, including health care, child custody, child protection and child welfare generally. Most obviously these commitments can be found at the heart of two of the most important articles within the UNCRC, namely articles 3(1) and 12(1):

Article 3(1):

In all actions concerning children, whether undertaken by public or private social welfare institutions, courts of law, administrative authorities or legislative bodies, the best interests of the child shall be a primary consideration.

Article 12(1):

Parties shall assure to the child who is capable of forming his or her own views the right to express those views freely in all matters affecting the child, the views of the child being given due weight in accordance with the age and maturity of the child.

As explained in the problem statement, it often occurs in practice that the requirements contained in legal instruments are not satisfied in practice, and professionals do not apply what is required by the legal instruments. The researchers found that often the two central commitments - namely to promote the child's best interests or the child's welfare, and to allow the child to express his or her view of any matter affecting his or her interests (where these views are given a weight proportionate to the child's maturity, age and understanding of these issues) (Archard \& Skivenes, 2009:1; Gould \& Martindale, 2009:33; Stahl, 1999:25) - are 
ignored in parenting plans and this defeats the real purpose of a parenting plan, which is meant to protect the child after divorce.

It is the researchers' view that these two commitments need to be clearly reflected in the process of facilitating intervention with divorcing families when parenting plans are being drafted. The reason for this is that often the child's wishes and best interest are overlooked when the process is facilitated with the family and when relevant information for a parenting plan is obtained, because the parents are often regarded as the client instead of the child. When parenting plans were drafted in the past, children also did not have the opportunity to express their views of any matter affecting their interests, again because professionals focused on the parents and not on the children. The researchers are aware of professionals who often do not include or consult the children in the intervention process pertaining to parenting plans. This is a clear indication that the child's views are not being considered or prioritised in parenting plans.

The following articles from the UNCRC can also add value to the process when working with divorce matters, and they should be considered in preparing a parenting plan. When plans are being prepared, it is imperative that professionals give attention to the child's position and protection, and that they should prevent the parents' opinion from dominating the process, so that the child does not end up feeling suppressed and discriminated against. It is thus imperative to promote and protect the child in the intervention process pertaining to parenting plans, in accordance with the guidelines provided by articles 2(2) and 19(1) of the UNCRC:

Article 2(2)

Parties shall take all appropriate measures to ensure that the child is protected against all forms of discrimination or punishment on the basis of the status, activities, expressed opinions, or beliefs of the child's parents, legal guardians, or family members.

\section{Article 19(1)}

Parties shall take all appropriate legislative, administrative, social and educational measures to protect the child from all forms of physical or mental violence, injury or abuse, neglect or negligent treatment, maltreatment or exploitation, including sexual abuse, while in the care of parent(s), legal guardian(s) or any other person who has the care of the child.

An important aspect of the parenting plan is to promote the child-parent relationship and all aspects should be considered to protect this relationship. Articles 9 and 10 of the UNCRC should be taken into account for this purpose:

\section{Article 9:}

Parties shall ensure that a child shall not be separated from his or her parents against their will, except when competent authorities subject to judicial review determine, in accordance with applicable law and procedures, that such separation is necessary for the best interests of the child. Such determination may be necessary in a particular case such as one involving abuse or neglect of the child by the parents, or one where the parents are living separately and a decision must be made as to the child's place of residence. In any proceedings pursuant to paragraph 1 of the present article, all interested parties shall be given an opportunity to participate in the proceedings and make their views known. States Parties shall respect the right of the child who is separated from one or both parents to maintain personal relations and direct contact with both parents on a regular basis, except if it is contrary to the child's best interests. 
Article 10:

A child whose parents reside in different States shall have the right to maintain on a regular basis, save in exceptional circumstances personal relations and direct contact with both parents. Towards that end and in accordance with the obligation of States Parties under article 9, paragraph 1, States Parties shall respect the right of the child and his or her parents to leave any country, including their own, and to enter their own country. The right to leave any country shall be subject only to such restrictions as are prescribed by law and which are necessary to protect the national security, public order (order public), public health or morals or the rights and freedoms of others and are consistent with the other rights recognized in the present Convention.

Furthermore, it is imperative that parenting plans focus on the responsibility of the parents. This is an important aspect of the preparation of plans, as it is imperative that parents' responsibilities are clearly defined in the plan. Articles 5, 18(1) and 27 should be considered in this case:

\section{Article 5:}

Parties shall respect the responsibilities, rights and duties of parents or, where applicable, the members of the extended family or community as provided for by local custom, legal guardians or other persons legally responsible for the child, to provide, in a manner consistent with the evolving capacities of the child, appropriate direction and guidance in the exercise by the child of the rights recognized in the present Convention.

Article 18(1):

Parties shall use their best efforts to ensure recognition of the principle that both parents have common responsibilities for the upbringing and development of the child. Parents or, as the case may be, legal guardians, have the primary responsibility for the upbringing and development of the child. The best interests of the child will be their basic concern.

\section{Article 27:}

Parties recognize the right of every child to a standard of living adequate for the child's physical, mental, spiritual, moral and social development. The parent(s) or others responsible for the child have the primary responsibility to secure, within their abilities and financial capacities, the conditions of living necessary for the child's development.

The researchers identified a number of main themes in the provisions of the UNCRC which are relevant for this study. Figure 1.1 illustrates 14 important aspects which the researchers have deduced from the UNCRC to be considered by professionals when they are preparing a parenting plan. 


\section{FIGURE 1 \\ ASPECTS TO CONSIDER WHEN PREPARING A CHILD-CENTRED PARENTING PLAN}

Protection of the child is of paramount importance [UNCRC: A(2)]

The child should maintain personal relations and direct contact with both parents on a regular basis [UNCRC: A(9.3)]

Children should not be separated from their parents except in special circumstances [UNCRC: A(9.1)]

Best interest of the child should be prioritised and should be the basic concern of the parents [UNCRC: A(3); A(18.1)]

A child should be heard in proceedings [UNCRC: A(12.2)]

Children must express their views if capable [UNCRC: A(12.1)]

A child has a right to a certain standard of living to promote their development [UNCRC: A(27.1)]

On relocation children should have the right to maintain contact on a regular basis with the parent [UNCRC: A(10)]

A child must be protected against abuse, neglect, negligent treatment, maltreatment, and exploitation [UNCRC: A(19.1)]

Caregiving and protection must conform to certain standards [UNCRC: A(3.3)]

Both parents have a common primary responsibility for the upbringing and development of their children [UNCRC: A(18.1)]

Parents must give direction and guidance to their children [UNCRC: A(5)]

Parents' responsibilities, rights, and duties must be respected [UNCRC: A(5)]

All parties should participate in intervention [UNCRC: A(9.2)]

When professionals work with divorcing families and when they are drafting parenting plans, the aspects reflected in Figure 1.1 should be used as a guideline. This will give direction to the professional to draft well-structured parenting plans with high-quality recommendations for the divorcing family.

Below, the African Charter on the Rights and Welfare of the Child will also be considered for further insights that can be used in drawing up parenting plans.

\section{AFRICAN CHARTER ON THE RIGHTS AND WELFARE OF THE CHILD}

The African Charter on the Rights and Welfare of the Child (ACRWC) was adopted by the Organisation of African Unity (OAU) in 1990, which legally became the African Union in 2001. South Africa endorsed this document in 1999. Like the UNCRC, the ACRWC is a comprehensive instrument that sets out rights and defines universal principles and norms for the status of children. The ACRWC and the UNCRC are international and regional human rights treaties that cover the whole spectrum of rights (Situational Analysis of Children in South Africa, 2009:vi).

For this research a number of articles of the ACRWR were identified that can add value for the professional when facilitating intervention in parenting plans. When a parenting plan is prepared, it is of paramount importance to focus on the child: this entails the promotion of the child's rights and the best interest of the child, and endorsing the development and functioning of the child as a human being. This includes the promotion of freedom of expression and taking 
the views of the child into consideration in all decisions or recommendations. Articles 4, 7, 9 and 12 of the ACRWC should be considered in this process:

\section{Article 4:}

In all actions concerning the child undertaken by any person or authority the best interests of the child shall be the primary consideration. In all judicial or administrative proceedings affecting a child who is capable of communicating his/her own views, an opportunity shall be provided for the views of the child to be heard either directly or through an impartial representative as a party to the proceedings, and those views shall be taken into consideration by the relevant authority in accordance with the provisions of appropriate law.

\section{Article 7:}

Every child who is capable of communicating his or her own views shall be assured the rights to express his opinions freely in all matters and to disseminate his opinions subject to such restrictions as are prescribed by laws.

Article 9:

Every child shall have the right to freedom of thought, conscience and religion. Parents, and where applicable, legal guardians shall have a duty to provide guidance and direction in the exercise of these rights having regard to the evolving capacities, and best interests of the child. States Parties shall respect the duty of parents and where applicable, legal guardians to provide guidance and direction in the enjoyment of these rights subject to the national laws and policies.

Article 12:

States Parties recognize the right of the child to rest and leisure, to engage in play and recreational activities appropriate to the age of the child and to participate freely in cultural life and the arts. States Parties shall respect and promote the right of the child to fully participate in cultural and artistic life and shall encourage the provision of appropriate and equal opportunities for cultural, artistic, recreational and leisure activity.

Parenting plans should focus on parental rights and responsibilities in relation to the child. These rights and responsibilities should be clearly specified in the plan to ensure that parents understand their roles pertaining to their children and their roles in the post-divorce family. Articles 11(4), 18, 19 and 20 of the ACRWC should be taken into account when parents' rights, duties and responsibilities as caregivers of their children are being considered:

Article 11(4):

States Parties to the present Charter shall respect the rights and duties of parents, and where applicable, of legal guardians to choose for their children schools, other than those established by public authorities, which conform to such minimum standards may be approved by the State, to ensure the religious and moral education of the child in a manner with the evolving capacities of the child.

Article 18:

The family shall be the natural unit and basis of society. It shall enjoy the protection and support of the State for its establishment and development. States Parties to the present Charter shall take appropriate steps to ensure equality of rights and responsibilities of 
spouses with regard to children during marriage and in the event of its dissolution. In case of the dissolution, provision shall be made for the necessary protection of the child. No child shall be deprived of maintenance by reference to the parents' marital status.

Article 19:

Every child shall be entitled to the enjoyment of parental care and protection and shall, whenever possible, have the right to reside with his or her parents. No child shall be separated from his parents against his will, except when a judicial authority determines in accordance with the appropriate law, that such separation is in the best interest of the child. Every child who is separated from one or both parents shall have the right to maintain personal relations and direct contact with both parents on a regular basis.

\section{Article 20:}

Parents or other persons responsible for the child shall have the primary responsibility of the upbringing and development the child and shall have the duty: (a) to ensure that the best interest of the child are their basic concern at all times-(b) to secure, within their abilities and financial capacities, conditions of living necessary to the child's development; and (c) to ensure that domestic discipline is administered with humanity and in a manner consistent with the inherent dignity of the child.

The ACRWC plays an important role in protecting the rights of children in an African context. Although the rights it describes are similar to those in the UNCRC, it is specifically focused on the unique circumstances of the African child. The ACRWC puts children's rights in legal and cultural perspective. In order for the ACRWC to have significance for children's rights in Africa and effectively change children's lives, people and member states collectively need to believe in and accept children's rights as human rights and recognise binding duties on them. It is a key source of inspiration for African member states and represents a collective recognition of the rights and welfare of African children, and it establishes a legal framework for their protection (Lloyd, 2002:11).

The following aspects that are derived from the ACRWC (see Figure 1.2) are important for the purpose of this research and should be consulted when parenting plans are drafted, to ensure that the African child's rights are being promoted in the parenting plans.

Figures 1.1 and 1.2 highlight important criteria that should be applied by the professional who is facilitating intervention with the divorcing family during the process of drafting a parenting plan. The following criteria are set by both the UNCRC and the ACRWC and are of primary importance for parenting plans:

- The best interest of the child;

- The child's views and opinions;

- Recreational activities for the child;

- Maintenance for the child;

- Parental care and protection of the child;

- The child's contact with parents when the parents are separated or when parents relocate; and

- The child's standard of living. 
FIGURE 1

ASPECTS TO BE CONSIDERED WHEN DRAFTING A PARENTING PLAN IN AN AFRICAN CONTEXT
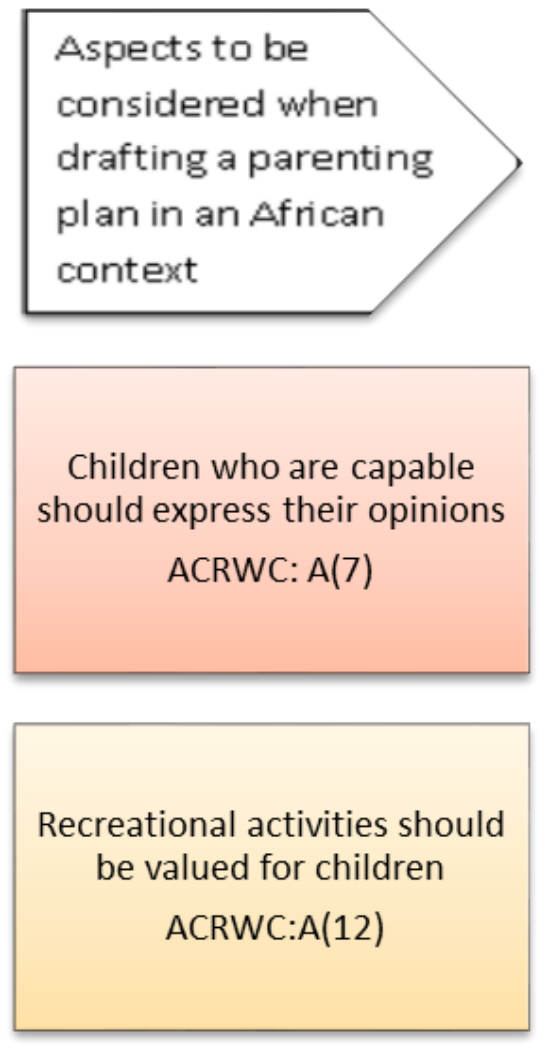

The child has the right to reside with his/her parent ACRWC:A(19.1)
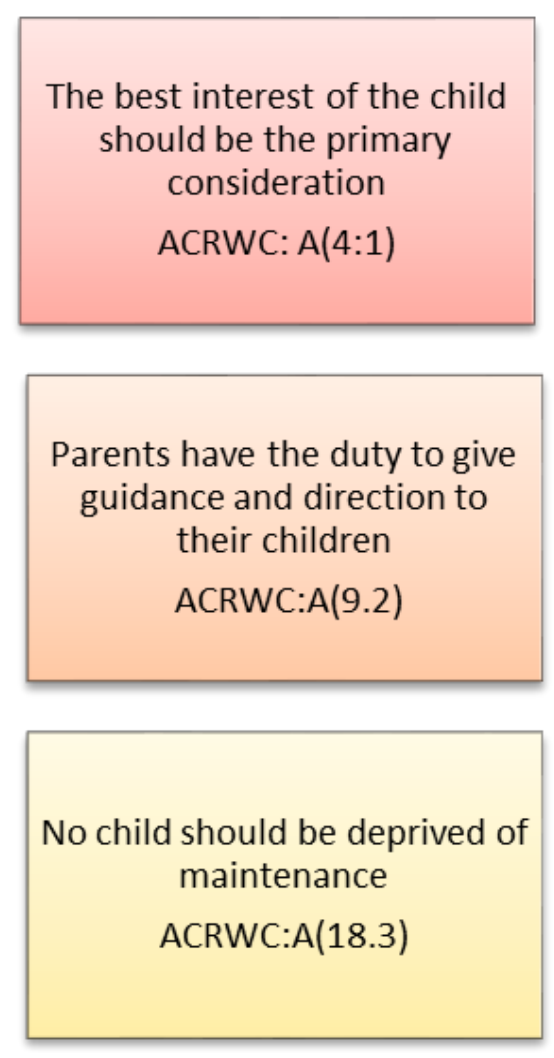

The child has the right to a personal and direct relationship with separated parents ACRWC:A(19.2)
The child's views are of importance ACRWC: A (4.2)

Parents have the right and duty to choose the children's schools ACRWC:A(11.4)

The child has the right to parental care and protection ACRWC:A(19.1)

Parents have primary responsibility for the upbringing and development of their children

ACRWC:A(20.1)

After compliance with these criteria, the following points in the UNCRC and ACRWC should be addressed by the parenting plan:

- Responsibilities, rights and duties of the parents;

- The direction and guidance parents should give their children;

- The primary responsibility of the parents for the children's upbringing and development; and

- The fact that the basic concern of the parent should be the best interest of the child.

Below, the Children's Act will also be discussed in as far as it contributes guidelines for a wellformulated parenting plan.

\section{THE CHILDREN'S ACT}

The Children's Act adopts a developmental approach that emphasises the state's role in the provision of social services to strengthen the capacity of families and communities to care for and protect children. The Children's Act has done a lot to improve the environment for the 
protection of children. The South African judicial system has significantly improved in terms of promoting children's rights and processing children's issues (Situational Analysis of Children in South Africa, 2009:iv). The Children's Act gives effect to certain rights of children as contained in the Constitution. Two specific sections of the Children's Act that are indispensable for parenting plans will be analysed here, namely section 7 (best interest of child standard) and sections 33 and 34 (contents and formalities with regard to parenting plans).

\section{Best interest of child standard}

Since the circumstances of each child in each family unit vary across a wide spectrum of factors, the best interest of child standard is inevitably a relative concept (Gould \& Martindale, 2009:33; Maya, 2005; Stahl, 1999:25). The facts and context of each case determine not only which interests, but also what factors, are to be considered. Generally, the child's interests include his or her physical, economic, emotional, intellectual, cultural, spiritual, social, moral and religious wellbeing. It is impossible to compile an exhaustive list of all the factors which must be considered when a court has to decide on a child's best interests. Yet these interests should be incorporated in the process of drafting the parenting plan.

Bekink (2003:15), Currie and De Waal (2005:617) and Strous (2007:223) emphasise that the best interest test directs the court to exercise the discretion it possesses in its capacity as upper guardian of minors to promote the interest of the child, rather than to focus on the rights and entitlements of the parents. However, the concept of the 'best interest of the child' is not unproblematic. It has become controversial because it has failed in the past to provide a reliable or determinate standard. In addition, it created the risk of social engineering through what the helping professions or social services consider to be in the best interests of the child. Nevertheless, in South African law the best interest of children is paramount: as indicated above, this principle is also embodied in the UNCRC and ACRWC (both of which South Africa has endorsed) and section 28(2) of the Constitution.

As indicated above, the child's interest should be determined by considering the terms contained in the Children's Act. Factors reflected in cases such as McCall vs McCall should also add value to determining the best interest of child standard. The McCall vs McCall criteria are frequently referred to in divorce disputes, although judges are not compelled to take all the criteria of that case into account. As useful as it may be, then, the McCall vs McCall list serves only as a guide (Barratt, 2003:145). Table 1.1 illustrates the terms in section 7 of the Children's Act and factors in the McCall vs McCall case, and points out correspondences and unique features between the two:

Table 1.1 reflects the factors that need to be considered when the best interest of child principle is being determined. The researchers experienced in practice that the principles for best interest of child standard, as contained in the newly enacted Children's Act and the McCall vs McCall criteria, do not always receive the necessary attention when parenting plans are drafted, because the parents dominate the process and the child's interests are overlooked in the facilitated intervention. It is of paramount importance that the best interest of child standard is the focus for the professional when the process with the divorcing family is being facilitated and when a parenting plan is being drafted. Professionals often feel passionate about the best interest of the child and will often discuss this with fellow-professionals working on the case; but this is seldom reflected in professional recommendations made in the parenting plans. Therefore it is pertinent that the best interest of the child standard should be an integral part of the intervention facilitated with the divorcing family and of the drafting of the parenting plan. 
TABLE 1

FACTORS TO CONSIDER WHEN DETERMINING THE BEST INTEREST OF THE CHILD

\begin{tabular}{|c|c|c|c|}
\hline $\begin{array}{l}\text { Factors in section } 7 \text { of the } \\
\text { Children's Act }\end{array}$ & $\begin{array}{l}\text { Factors in the South } \\
\text { African case of McCall vs } \\
\text { McCall }\end{array}$ & $\begin{array}{l}\text { CORRESPONDING } \\
\text { FACTORS } \\
\text { considered by both } \\
\text { the Children's Act } \\
\text { and in the case of } \\
\text { McCall vs McCall }\end{array}$ & $\begin{array}{l}\text { UNIQUE FACTORS } \\
\text { considered by section } \\
7 \text { of the Children's } \\
\text { Act and in the case of } \\
\text { McCall vs McCall }\end{array}$ \\
\hline $\begin{array}{l}\text { The nature of the personal } \\
\text { relationship between (i) the } \\
\text { child and the parents, or any } \\
\text { specific parent; and (ii) the } \\
\text { child and any other care- } \\
\text { giver or person relevant in } \\
\text { those circumstances. }\end{array}$ & $\begin{array}{l}\text { The love, affection and } \\
\text { emotional ties that exist } \\
\text { between parent and child, } \\
\text { and the parent's } \\
\text { compatibility with the child. }\end{array}$ & $\begin{array}{l}\text { Bond between the } \\
\text { child and the parent. }\end{array}$ & $\begin{array}{l}\text { Act extended to other } \\
\text { caregivers, for example, } \\
\text { grandparents. }\end{array}$ \\
\hline $\begin{array}{l}\text { (i) The attitude of the parents, } \\
\text { or any specific parent, } \\
\text { towards the child; and (ii) the } \\
\text { exercise of parental } \\
\text { responsibilities and rights in } \\
\text { respect of the child. }\end{array}$ & $\begin{array}{l}\text { The ability of the parent to } \\
\text { communicate with the child, } \\
\text { and the parent's insight into, } \\
\text { understanding of, and } \\
\text { sensitivity to the child's } \\
\text { feelings. The capacity and } \\
\text { disposition of the parent to } \\
\text { give the child the guidance } \\
\text { that he or she requires. }\end{array}$ & $\begin{array}{l}\text { The ability of the } \\
\text { parent to add value to } \\
\text { the child's life and } \\
\text { sensitivity. }\end{array}$ & $\begin{array}{l}\text { McCall indicates } \\
\text { sensitivity towards the } \\
\text { child. }\end{array}$ \\
\hline $\begin{array}{l}\text { The capacity of the parents, } \\
\text { or any specific parent, or any } \\
\text { other care-giver or person, to } \\
\text { provide for the needs of the } \\
\text { child, including emotional } \\
\text { and intellectual needs. }\end{array}$ & $\begin{array}{l}\text { The capabilities, character, } \\
\text { and temperament of the } \\
\text { parent and their impact on } \\
\text { the child's needs and desires. } \\
\text { The ability of the parent to } \\
\text { provide for the education, } \\
\text { wellbeing and security of the } \\
\text { child, both religious and } \\
\text { secular. }\end{array}$ & $\begin{array}{l}\text { The parent's ability to } \\
\text { provide for the needs } \\
\text { of the child. Not only } \\
\text { financially but } \\
\text { emotionally and } \\
\text { intellectually. }\end{array}$ & $\begin{array}{l}\text { The ability of the parent } \\
\text { to provide financially } \\
\text { for the child. }\end{array}$ \\
\hline $\begin{array}{l}\text { The likely effect on the child } \\
\text { of any change in the child's } \\
\text { circumstances, including the } \\
\text { likely effect on the child of } \\
\text { any separation from (i) both } \\
\text { or either of the parents; or (ii) } \\
\text { any brother or sister or other } \\
\text { child; or (iii) any other care- } \\
\text { giver or person with whom } \\
\text { the child has been living. }\end{array}$ & $\begin{array}{l}\text { The desirability or otherwise } \\
\text { of keeping of siblings } \\
\text { together. }\end{array}$ & $\begin{array}{l}\text { The desirability to } \\
\text { keep family members } \\
\text { together to avoid } \\
\text { separation from a } \\
\text { member. }\end{array}$ & $\begin{array}{l}\text { The Act includes other } \\
\text { care takers, for } \\
\text { example, grandparents. }\end{array}$ \\
\hline $\begin{array}{l}\text { The practical difficulty and } \\
\text { expense of a child having } \\
\text { contact with the parents, or } \\
\text { any specific parent, and } \\
\text { whether that difficulty or } \\
\text { expense will substantially } \\
\text { affect the child's right to } \\
\text { maintain personal relations } \\
\text { and direct contact with the } \\
\text { parents, or any specific } \\
\text { parent, on a regular basis. }\end{array}$ & & & $\begin{array}{l}\text { The practical difficulty } \\
\text { and expense of a child } \\
\text { to have contact with a } \\
\text { parent. }\end{array}$ \\
\hline
\end{tabular}




\begin{tabular}{|c|c|c|c|}
\hline $\begin{array}{l}\text { Factors in section } 7 \text { of the } \\
\text { Children's Act }\end{array}$ & $\begin{array}{l}\text { Factors in the South } \\
\text { African case of McCall vs } \\
\text { McCall }\end{array}$ & $\begin{array}{l}\text { CORRESPONDING } \\
\text { FACTORS } \\
\text { considered by both } \\
\text { the Children's Act } \\
\text { and in the case of } \\
\text { McCall vs McCall }\end{array}$ & $\begin{array}{l}\text { UNIQUE FACTORS } \\
\text { considered by section } \\
7 \text { of the Children's } \\
\text { Act and in the case of } \\
\text { McCall vs McCall }\end{array}$ \\
\hline $\begin{array}{l}\text { The need for the child (i) to } \\
\text { remain in the care of his or } \\
\text { her parent, family and } \\
\text { extended family; and (ii) to } \\
\text { maintain a connection with } \\
\text { his or her family, extended } \\
\text { family, culture or tradition. }\end{array}$ & $\begin{array}{l}\text { The child's preference, if the } \\
\text { court is satisfied that in the } \\
\text { particular circumstances it } \\
\text { should be taken into } \\
\text { consideration. }\end{array}$ & $\begin{array}{l}\text { The child's need and } \\
\text { preference. }\end{array}$ & $\begin{array}{l}\text { Role of legal } \\
\text { representative in terms } \\
\text { of Section 28(1)(h). }\end{array}$ \\
\hline $\begin{array}{l}\text { The child's (i) age, maturity } \\
\text { and stage of development; } \\
\text { (ii) gender; (iii) background; } \\
\text { and (iv) any other relevant } \\
\text { characteristics of the child. } \\
\text { The child's physical and } \\
\text { emotional security and his or } \\
\text { her intellectual, emotional, } \\
\text { social and cultural } \\
\text { development. }\end{array}$ & $\begin{array}{l}\text { The ability of the parent to } \\
\text { provide for the child's } \\
\text { emotional, psychological, } \\
\text { cultural, and environmental } \\
\text { development. }\end{array}$ & $\begin{array}{l}\text { The parent's ability to } \\
\text { enhance the child's } \\
\text { development. }\end{array}$ & $\begin{array}{l}\text { Any relevant } \\
\text { characteristic of the } \\
\text { child. }\end{array}$ \\
\hline $\begin{array}{l}\text { Any disability that a child } \\
\text { may have. Any chronic } \\
\text { illness from which a child } \\
\text { may suffer. }\end{array}$ & & & $\begin{array}{l}\text { Any disability of a } \\
\text { child. Any chronic } \\
\text { illness of a child. }\end{array}$ \\
\hline $\begin{array}{l}\text { The need for a child to be } \\
\text { brought up within a stable } \\
\text { family environment and, } \\
\text { where this is not possible, in } \\
\text { an environment resembling } \\
\text { as closely as possible a caring } \\
\text { family environment. }\end{array}$ & $\begin{array}{l}\text { The stability or otherwise of } \\
\text { the child's existing } \\
\text { environment, having regard } \\
\text { for the desirability of } \\
\text { maintaining the status quo. }\end{array}$ & $\begin{array}{l}\text { The stability of the } \\
\text { child's environment. }\end{array}$ & \\
\hline $\begin{array}{l}\text { The need to protect the child } \\
\text { from any physical or psycho- } \\
\text { logical harm that may be } \\
\text { caused by (i) subjecting the } \\
\text { child to maltreatment, abuse, } \\
\text { neglect, exploitation or de-- } \\
\text { gradation or exposing the } \\
\text { child to violence or exploita- } \\
\text { tion or other harmful beha- } \\
\text { viour; or (ii) exposing the } \\
\text { child to maltreatment, abuse, } \\
\text { degradation, ill-treatment, } \\
\text { violence or harmful beha- } \\
\text { viour towards another person. }\end{array}$ & $\begin{array}{l}\text { The mental and physical } \\
\text { health and moral fitness of } \\
\text { the parent. }\end{array}$ & $\begin{array}{l}\text { To protect the child } \\
\text { from any physical, } \\
\text { mental, and moral } \\
\text { harm. }\end{array}$ & \\
\hline $\begin{array}{l}\text { Any family violence } \\
\text { involving the child or a } \\
\text { family member of the child. }\end{array}$ & & & $\begin{array}{l}\text { Any violence involving } \\
\text { the child. }\end{array}$ \\
\hline $\begin{array}{l}\text { Which action or decision } \\
\text { would avoid or minimise } \\
\text { further legal or administrative } \\
\text { proceedings in relation to the } \\
\text { child. }\end{array}$ & & & $\begin{array}{l}\text { Actions or decision to } \\
\text { avoid or minimise } \\
\text { further intervention } \\
\text { involving the child. }\end{array}$ \\
\hline
\end{tabular}




\begin{tabular}{|l|l|l|l|}
\hline $\begin{array}{l}\text { Factors in section } 7 \text { of the } \\
\text { Children's Act }\end{array}$ & $\begin{array}{l}\text { Factors in the South } \\
\text { African case of McCall vs } \\
\text { McCall }\end{array}$ & $\begin{array}{l}\text { CORRESPONDING } \\
\text { FACTORS } \\
\text { considered by both } \\
\text { the Children's Act } \\
\text { and in the case of } \\
\text { McCall vs McCall }\end{array}$ & $\begin{array}{l}\text { UNI of the Children's } \\
\text { 7ct and in the case of } \\
\text { McCall vs McCall }\end{array}$ \\
\hline & $\begin{array}{l}\text { The ability of the parent to } \\
\text { provide for the child's } \\
\text { physical and material needs } \\
\text { and economic security. }\end{array}$ & $\begin{array}{l}\text { Same-sex matching. } \\
\text { of applying the doctrine of } \\
\text { same-sex matching. }\end{array}$ & Any other factor. \\
\hline & $\begin{array}{l}\text { Any other factor that is } \\
\text { relevant to the particular case } \\
\text { with which the court is } \\
\text { concerned. }\end{array}$ & & \\
\hline
\end{tabular}

When the parenting plan is compiled, the best interest of the child should be identified according to the guidelines set out by legal instruments. To this end, legislation pertaining to the contents and formalities with regard to parenting plans will be discussed below.

\section{Contents and formalities with regard to parenting plans}

Sections 33 and 34 of the Children's Act are relevant to this study, and the researcher will therefore give a brief summary of these sections.

The contents of parenting plans should reflect the best interest of the child standard. Parents must seek the assistance of a family advocate, social worker or psychologist; or mediation through a social worker or other suitably qualified person when a parenting plan is prepared. In some instances parents may agree on a parenting plan that determines the exercise of their respective responsibilities and rights in respect of the child. However, if the parents are in conflict, they must first seek to agree on a parenting plan before they seek the intervention of a court. A parenting plan may determine any matter in connection with parental responsibilities and rights, including where and with whom the child is to live; the maintenance of the child; contact structures; schooling; and religious upbringing of the child.

Parenting plans must conform to certain formalities. A parenting plan must be in writing, it must be signed by the parties to the agreement, and it may be registered with a family advocate or made an order of the court. An application by parents for the registration of the parenting plan or for it to be made an order of the court must be in the prescribed format and it must contain the prescribed particulars. It must be accompanied by a copy of the plan and a statement by a family advocate, social worker or psychologist declaring that the plan was prepared after consultation or mediation with such a professional. A parenting plan registered with a family advocate may be amended or terminated by the family advocate on application by the parents. A parenting plan that was made an order of the court may be amended or terminated only by an order of the court on application by the parents who are parties to the plan; by the child, acting with leave of the court; or in the child's interest, by any other person acting with leave of the court.

Parenting plans are a relatively new phenomenon in South Africa, and the researchers therefore believe that the professional should use all available resources to produce effective and high- 
quality parenting plans. Because parenting plans for divorcing families must be compiled before the courts are approached, it is imperative that appropriate, sound, well-structured and professionally designed parenting plans be drafted by competent, well-informed and appropriately qualified professionals. Connell (2008:9) points out that disputes about parenting time and responsibility occupy much of the time of family courts and of forensic mental health professionals who perform evaluations for these courts. The legal approach to these matters continues to evolve with societal changes in the ways parenting is viewed. Certain trends are reviewed, including expanded concepts of family constellations, the current emphasis on shared parenting, and shifts in the language employed by the law. Courts are finding alternative ways to resolve conflict for families, who can benefit from education and brief intervention. The internet has had an impact on parent education, service delivery and the promulgation of collective wisdom and community philosophy. Forensic mental health evaluations are increasingly used in cases where there are allegations of sexual abuse, alienation, chemical dependency or partner violence, or when relocation is an issue. Professional standards and guidelines for these evaluations emphasise the importance of neutrality and of collecting relevant and reliable data. In the context of refined expectations for expert testimony, and with increasingly educated examinees, heightened attention is being given to the quality of the evaluation and the competency of the evaluator. These refined expectations place pressure on the professional to deliver high-quality parenting plans; and with effective training, professionals can meet these expectations.

Sections 33 and 34 of the Children's Act give guidance to the professional on the content and formalities of parenting plans and on how to deliver quality work in a competent manner. This in itself will assist the uninformed professional to support divorcing families in the intervention pertaining to parenting plans and the administration process surrounding the parenting plan. The drafting of parenting plans is a relatively new concept for South African professionals and not all professionals are fully prepared for this task or have received adequate training from an accredited institution to facilitate intervention pertaining to divorcing families and the drafting of parenting plans. When incompetent professionals are involved in the process, parenting plans are often not child-centred and the intervention with the divorcing family is of poor quality. Emphasis should thus be placed on assisting the professional with substantive and comprehensive guidelines that are clear on the basic process structure and general content of parenting plans, to assist the professional to deliver competent and high-quality parenting plans.

\section{CONCLUSION}

The researcher posed the following research question in the problem statement: What legal issues and factors do professionals have to consider when a parenting plan is created? Through a critical analysis of the relevant legal instruments, the following answer to this question was construed.

In order for professionals to compile a parenting plan the several guidelines should be taken into consideration, as noted below.

The professional should be well versed with regard to the legal instruments pertaining to children and children's rights. These legal instruments should be used as a guideline to ensure that the professional facilitates intervention and drafts plans within the relevant legal framework. The professional should thus directly refer to legal instruments in the plan, as this will enhance the quality of the plans drafted by informed professionals. 
The professional should draft child-centred and not parent-centred parenting plans and the following rights of the child should be prioritised in drafting the plan: (1) the child's right to parental care; (2) the child's right to protection; (3) the child's right to legal representation; and (4) the child's best interest. The professional should use these four points (as derived from section 28 of the Constitution) to facilitate the intervention process with the divorcing family. After completing the parenting plan for the divorcing family, the professional should ask whether the plan indeed reflects the child's right to parental care, the child's right to protection, the child's right to legal representation and the best interest of the child. If the parenting plan does not satisfy these four requirements, the professional should reconsider the recommendations of the plan because the plan is then most likely not a child-centred plan.

Through a critical analysis of the relevant legal instruments, it was concluded that the UNCRC and ACRWC (two international instruments) are indispensable for the professional who has to facilitate intervention with the divorcing family and draft parenting plans in South Africa. These are two comprehensive instruments that set out the rights and define the universal principles and norms for the status of children. They should be used as a guideline to help the professional to fully understand and accept the rights of the child and thus to promote the rights of the child accordingly. When these instruments are applied, the professional should use an approach that primarily focuses on and promotes the right of the child and that places the parent secondary in the intervention process. This will ensure high-quality and effective parenting plans.

The Children's Act is crucial for determining the nature and content of parenting plans as well as their necessity. Three sections in the Act are particularly relevant here: the best interest of child standard (section 7), and the contents and formalities pertaining to parenting plans (sections 33 and 34). These three sections demand that parenting plans be child-centred and that they accordingly provide guidelines to professionals to deliver structured plans in a wellorganised process of registry to ensure an effective parenting plan that works for the divorcing family. If professionals understand these sections, they will also understand what the focus of a parenting plan should be (as stipulated in section 7) and how to deliver quality work in a competent manner (as stipulated in sections 33 and 34).

It was pointed out that professionals are often ignorant about intervention pertaining to parenting plans and are unable to draw up high-quality parenting plans, because parenting plans are a relatively new phenomenon in South Africa and most professionals were not trained for the process. All professionals working with parenting plans should be well qualified in the field of parenting plans, but they must at least have a comprehensive understanding of the abovementioned sections of the Children's Act. These sections will guide professionals to deliver well thought-through parenting plans with the child's best interest at heart. Although mere knowledge and understanding of these sections do not qualify a professional to work in this complex field, they will nevertheless provide professionals with the basic tools to inform their clients on the importance of a parenting plan in the post-divorce stage.

The legal instruments discussed in this article emphasise the child's needs, wishes and sense of safety, and they ensure that the child's rights are respected, protected, promoted and fulfilled. The content of parenting plans, as prescribed by the Act, must determine any and all matters in connection with parental responsibilities and rights.

In order to develop high-quality parenting plans, professionals should consider various aspects that are important for the child, the parent and the professional in drafting the plans. With 
regard to the child it is imperative to prioritise the child in the divorcing family; consult with children in the intervention process and give a voice to the children to state their views and opinions; recognise that the best interest of the child is of primary importance; make the child the main focus of the intervention process and not the parents. With regard to the parents, it is imperative to inform the parents of the professional's ethical responsibility towards the child. Professionals ought to make informed decisions about cases, especially those cases where parents have consulted with various other professionals, as parents often seek recommendations that suit themselves; advise the divorcing family that the mother and father should be legally represented by their own respective legal counsel and that the children should have their own legal representation (if such representation is necessary in the opinion of the professional); focus on the child and do not get entangled with the dispute between the parents; act with professional integrity and respect co-professionals and their opinions; apply legal instruments; and consult other professionals if needed (such as a psychologist to establish the child's mental capacities).

The researcher strongly believes that to deliver workable parenting plans for the divorcing family, all parties need to give their full cooperation in the intervention process. Intervention with a divorcing family to structure a well-organised, practical and realistic parenting plan for each unique family can only be successful if professionals, parents and children all work together with the objective to make post-divorce family life more functional for all members of the family.

\section{REFERENCES}

ARCHARD, D. \& SKIVENES, M. 2009. Balancing a child's best interests and a child's views. International Journal of Children's Rights, 17(1):1-21.

BARRATT, A. 2003. 'The best interest of the child': Where is the child's voice? In: BURMAN, S. (ed) The fate of the child: legal decisions on children in the new South Africa. Lansdowne: Juta Law.

BASTOW, L. 2009. Parental responsibility. [Online] Available: http://www.bsdivorcesolicitors.co.uk [Accessed: 18/02/2009].

BEKINK, B. 2003. Parental religious freedom, rights and best interests of children. Journal of Contemporary Roman Dutch Law, 66:246-277.

CARTER, S., HAAVE, B. \& VANDERSTEEN, S. 2010. Family restructuring therapy for high conflict families. (AFCC 46th Annual Conference, Pre-Conference Institute. The Children's Law Centre: Hawaii.) [Online] Available: http://www.childlawhawaii.com/guidingvalues-for-child-centred-parenting-plans.php [Accessed: 01/04/2010].

CONNELL, M. 2008. Changes in the wind: parenting assessment in family dissolution matters. Journal of Psychiatry \& Law, 36:13-20.

CURRIE, I. \& DE WAAL, J. 2005. The Bill of Rights handbook $\left(5^{\text {th }}\right.$ ed). Lansdowne: Juta Law.

GOULD, J.W. \& MARTINDALE, D.A. 2009. The art and science of child custody evaluations $\left(3^{\text {rd }}\right.$ ed $)$. New York: Guilford Press.

LLOYD, A. 2002. The theoretical analysis of the reality of children's rights in Africa: an introduction to the African Charter on the Rights and Welfare of the Child. African Human Rights Law Journal, 2(1). 
MAYA, M.M.L. 2005. Judgment in the matter between Helen Margaret Ford, appellant, and Michael George William Ford, Respondent. In: The Supreme Court of Appeal of South Africa. Case No: 52/05. [Online] Available: http://www.supremecourtofappeal.gov.za /judgements/sca judg/sca 2005/52 05.pdf [Accessed: 02/04/2010].

PRETORIUS, S. 2008. Father's 4 justice. [Online] Available: http://www.fathers-4justice.co.za [Accessed: 08/10/2009].

RAMOLOTJA, A.M.A. 2000. Determining the best interest of the child. [Online] Available: http://www.unisa.ac.za [Accessed: 16/02/2009].

ROBINSON, T.M. 2009. Divorce: what about the children? Cape Town: Struik Publishers.

SITUATIONAL ANALYSIS OF CHILDREN IN SOUTH AFRICA. 2009. The Presidency, Republic of South Africa: Union Building. [Online] Available: www.thepresidency.gov.za [Accessed: 28/05/2010].

SOUTH AFRICA. 1996. Constitution of the Republic of South Africa as adopted by the Constitutional Assembly on 8 May 1996 and as amended on 11 October 1996. Pretoria: Government Printer.

SOUTH AFRICA. 2006. Children's Act, No. 38 of 2005. Government Gazette, 28944,20060619, notice $\mathrm{nr} 610$.

STAHL, P.M. 1999. Complex issues in child custody evaluations. Belmont, Calif.: Sage Publications.

STROUS, M. 2007. Post-divorce relocation: in the best interest of the child? South African Journal of Psychology, 37(2):223-244.

THAYER, E.S. \& ZIMMERMAN, J. 2001. The co-parenting survival guide. Oakland, Calif.: New Harbinger Publications.

WHITE, J.G. 2005. Winning with evidence: child custody A to Z. New York: Universe.

Ms Tanya Robinson, PhD candidate and social worker in private practice: Family Therapy Assessment Centre, Dainfern Valley, Gauteng; Prof Linda Stewart, Faculty of Law, North-West University (Potchefstroom Campus); Dr Elma Ryke, Dr Cornelia Wessels, School of Psychosocial Behavioural Sciences, Division Social Work, NorthWest University (Potchefstroom Campus), South Africa. 